Jurnal Pilar Teknologi, Volume 3 Nomor 2 Edisi September 2018

ISSN Print : 2502-7042 ISSN Online : 2580-3557

http://pilar.unmermadiun.ac.id

\title{
Pengembangan Sistem Informasi Geografi Bencana Alam Pada Kabupaten Madiun Berbasis Web Menggunakan Metode Build and Fix
}

\author{
Ezra Gayu Yuviega ${ }^{1}$, Pradityo Utomo ${ }^{2}$, Dwi Nor Amadi ${ }^{3}$

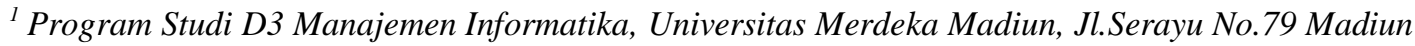 \\ E-mail: ezra.gayu@gmail.com \\ ${ }^{2}$ Program Studi D3 Manajemen Informatika, Universitas Merdeka Madiun, Jl.Serayu No.79 Madiun \\ E-mail: pradityo@unmer-madiun.ac.id \\ ${ }^{2}$ Program Studi D3 Manajemen Informatika, Universitas Merdeka Madiun, Jl.Serayu No.79 Madiun \\ E-mail:dwinor@unmer-madiun.ac.id
}

\begin{abstract}
Development Natural Disaster Information Geografis System is a website service utilizing digital map service. To facilitate the Regional Disaster Management Agency (BPBD) and the Community of Madiun Regency in providing and receiving information about the occurrence of Natural Disasters in Madiun District, the need for the application of information systems. The information system can display the points where the Natural Disasters occur. With the Information System, everyone can see the location of the map of the disaster occurrence area along with the description of the area. in this study developed a "Natural Disaster Information System at Madiun district". System development using Build and Fix method, because it is considered fast in making the system. The built system can be expected to assist BPBD officers in performing their duties. So that the system built must have the ability to form information accurately the occurrence of natural disasters. Therefore, the disaster information system in Madiun district has been tested using blackbox method, with $100 \%$ system success rate.
\end{abstract}

Keywords : Web, Madiun District, Natural Disaster, Information Geografis System, Build and Fix, Blackbox

\section{PENDAHULUAN}

Beberapa wilayah yang ada di Kabupaten Madiun terendifikasi rawan bencana banjir pada saat musim hujan. wilayah tersebut meliputi kecamatan Balerejo, kecamatan Sawahan, kecamatan Madiun, kecamatan Wungu, kecamatan Geger, kecamatan Kebonsari, kecamatan Jiwan, dan kecamatan Dagangan. Selain Banjir kabupaten Madiun juga terdapat wilayah rawan tanah longsor, wilayah tersebut meliputi, kecamatan Saradan, kecamatan Gemarang, kecamatan Wungu, kecamatan Kare dan kecamatan Dagangan. Wilayah Kecamatan Saradan yang rawan bencana tanah longsor meliputi, desa Sumberbendo, desa Klangon. Untuk wilayah kecamatan Gemarang meliputi, desa Winong, desa Batok, desa Durenan, desa Tawangrejo. Di kecamatan Wungu hanya desa Kresek yang rawan tanah longsor. Sedangkan untuk wilayah kecamatan Kare dan kecamatan Dagangan adalah wilayah rawan tanah longsor yang paling banyak terjadi (Kabupaten Madiun, 2013).

Untuk mempermudah Badan Penanggulanan Bencana Daerah (BPBD) dan Masyarakat Kabupaten Madiun dalam memberikan dan menerima informasi mengenai terjadinya Bencana Alam di Kabupaten Madiun, perlu adanya Aplikasi sistem informasi. Sistem informasi tersebut dapat menampilkan titik-titik letak Bencana Alam yang terjadi.

Penelitian tentang sistem informasi Geografi bencana alam pada kabupaten Madiun telah dilakukan pada tahun 2017. Di penelitian yang dibuat oleh Pratama dan Nita, menggunakan metode Waterfall. Sistem dapat memetakan titik-titik daerah yang terjadi bencana di Kabupaten Madiun guna membantu BPBD kabupaten madiun dalam memberikan informasi kepada masyarakat. Akan tetapi di sistem informasi tersebut belum ada fitur inputan dan fitur login admin sebagai keamanan. Untuk menambahkan data, 
user harus menggunakan cara manual dengan mengubah database. Penelitian tersebut menyarankan untuk menambahkan fitur inputan dan fitur login untuk admin. Sehingga pada penelitian ini dapat dikembangkang Sistem Informasi Bencana Alam pada kabupaten Madiun berbasis web dengan menggunakan metode Build and Fix serta penambahan fitur Inputan dan fitur login sebagai keamanan Sistem Informasi Bencana Alam Kabupaten Madiun (Pratama, Sekreningsih, 2017).

Teknologi Sistem Informasi Geografis (SIG) merupakan perangkat lunak yang berfungsi untuk memasukan, memanipulasi serta menampilkan informasi geografis beserta atribut-atributnya, sehingga teknologi SIG ini sangat cocok diterapkan dalam sistem informasi pengelolaan dan penanggulangan bencana alam.

Beberpa penelitian terkait Sistem Informasi Geografi Bencana Alam pernah dilakukan, diantaranya adalah Sistem Informasi Bencana Alam pada kota Padang, suatu sistem informasi geografi yang dapat membantu mengetahui letak terjadinya bencana alam pada kota padang. Penelitian yang dibuat oleh Andre, Erdisna dan Rianti tersebut, dirancang menggunakan pemodelan dengan diagram UML, dan bahasa pemograman yang digunakan adalah PHP dan database MySQL. Dari hasil perancangan tersebut menghasilkan Suatu sistem Informasi Bencana yang terjadi pada kota Padang (Andre dkk, 2015).

Pada tahun 2016, Sagita juga pernah melakukan penelitian tentang sistem informasi Bencana alam pada Jakarta Selatan khususnya bencana Banjir. Pada penelitian tersebut menggunakan metode pengumpulan data, implementasi, serta user interface sedangkan perancangan sistem informasi tersebut menggunakan perancangan UML dan perancangan Phonegab. Untuk bahasa pemograman yang digunakan adalah HTML, PHP, serta database menggunakan MySQL. Dari perancangan tersebut, menghasilkan suatu sistem informasi untuk mengetahui letak titik titik bencana banjir kota Jakarta selatan (Sagita, 2016).

Penelitian lainya tentang Sistem Informasi Geografi Bencana Alam, juga pernah dilakukan oleh Hidayat, Rahmat dan Mubarok, penelitian yang berjudul Sistem Informasi Geografi Daerah Rawan Tanah Longsor di kabupaten Tasikmalaya adalah sistem informasi untuk mengetahui daerah rawan tanah longsor yang ada di kota Tasikmalaya. Dalam sistem informasi tersebut dirancang Menggunakan metode waterfall serta perancangan menggunakan model UML dengan Bahasa pemograman PHP. Sistem informasi tersebut digunakan untuk membantu masyarakat dalam mengetahui daerah rawan longsor di kabupaten Tasikmalaya, serta membantu BPBD Tasikmalaya memberikan informasi daerah rawan bencana kepada masyarakat (Hidayat dkk, 2015).

Sistem Informasi Geografis Kawasan Bencana Alam Kabupaten Polewali Mandar dengan menggunakan Google Maps merupakan salah satu penelitian tentang Sistem Informasi Geografi Bencana Alam lainya. Penelitian Tersebut dilakukan oleh Hamka, Qashim dan Syarli pada tahun 2017. Sistem informasi tersebut, dapat menampilkan kawasan bencana yang ada di kabupaten Polewali Mandar yang menggunakan bantuan Google Maps dengan bahasa pemograman PHP serta database menggunakan MySQL (Hamka dkk, 2017).
Dari Penelitian yang pernah dilakukan dapat disimpulkan, sistem informasi geografi bencana alam berbasis web adalah sistem informasi yang menyediakan dan menampilkan peta lokasi bencana melalui web. Untuk membantu Badan Penanggulanan Bencana serta masyarakat khususnya kabupaten Madiun, maka Sistem Informasi Geografi Bencana Alam pada Kabupaten Madiun perlu dibuat.

\section{METODE PENELITIAN}

Build and Fix adalah sistem sangat mudah digunakan bagi pemula untuk pengembangan sistem informasi. Build and Fix sangat cocok digunakan pada proyek berskala kecil, serta kelebihan Build and Fix lainya adalah tidak terlalu banyak perencanaan (Dhami, 2016). Berikut adalah langkahlangkah menggunakan metode Build and Fix pada Gambar 1.

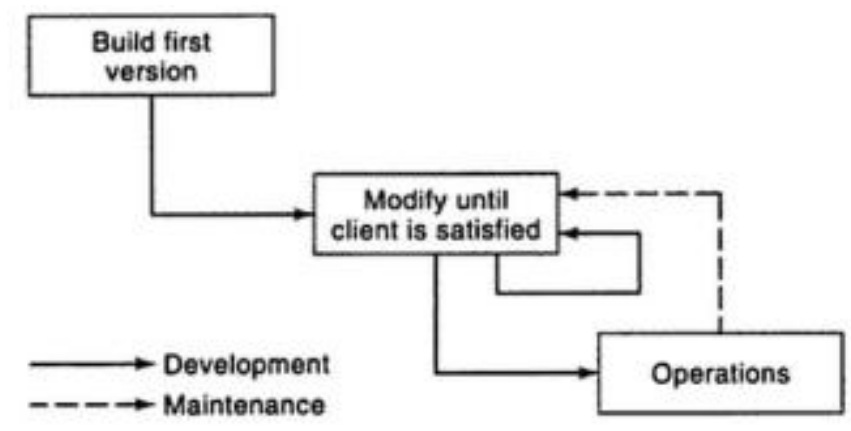

Gambar 1. Langkah-langkah Metode Build-and-Fix (Verma, 2014).

Pada Gambar 1 telah disajikan tahapan pembangunan sistem menggunakan metode Build and Fix.

1. Build First Version

Membuat proyek dari awal sampai jadi, di tahapan awal ini development tidak memodifikasi proyek.

2. Modify Until Client Satisfied

Melakukan perbaikan sistem atau memodifikasi sistem secara terus menerus menurut permintaan kebutuhan pelanggan atau user sampai sempurna atau fix.

3. Retirement

Proyek dinyatakaan selesai dan proyek dapat dijalankan oleh pelanggan atau user.

Sedangkan untuk Metode untuk pengujian sistem, menggunakan metode Black Box. Di dalam Metode Black Box menggunakan butir uji, Butir yang diuji antara lain, butir uji user dan butir uji admin. Butir uji User terdiri dari, halaman utama (Home), halaman data bencana, halaman peta perseberan bencana, halaman berita, login admin, dan halaman about. Sedangkan untuk butir uji admin terdiri dari halaman login, halaman olah data bencana, halaman tambah bencana, hapus data bencana, cetak data bencana, halaman olah data berita, tambah berita, hapus berita dan logout.

\section{HASIL DAN PEMBAHASAN}

Untuk menggambarkan basis data dari sistem dapat menggunakan Entity Relationship Diagram (ERD) yang menghubungkan antar objek dan atribut dari data. 
Berdasarkan diagram ER pada Gambar 2 diatas, dapat dijelaskan sebagai berikut, Pada table login terdapat users, password dan nama. Pada tabel bencana terdapat id_bencana, nama_bencana, kategori, korban, tanggal, alamat, kecamatan, status, latitude, dan longitude, dimana id_bencana sebagai primary key.

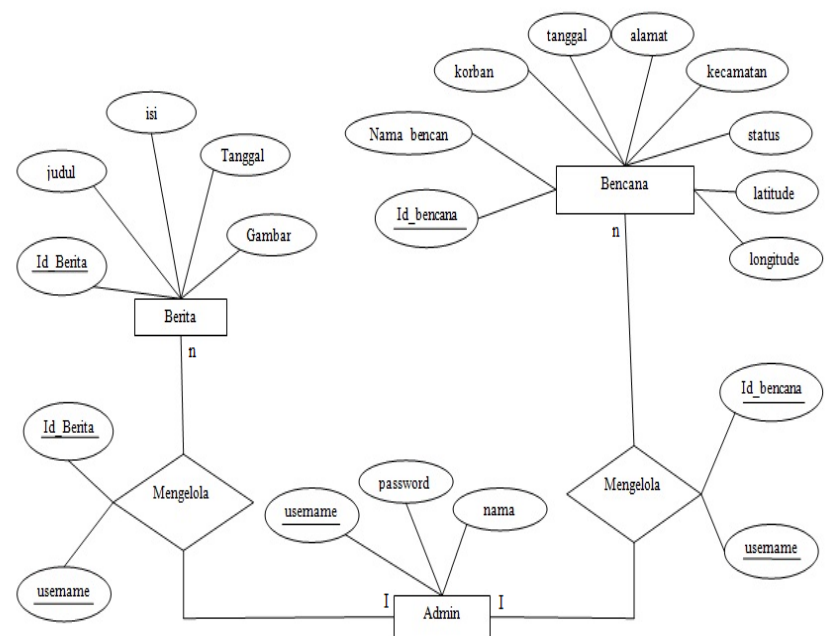

Gambar 2. ERD Sistem.

Dalam pengembangan sistem informasi geografi bencana alam pada kabupaten Madiun menggunakan perancangan model UML. Diagram UML yang akan digunakan dalam pengembangan sistem informasi bencana alam ini antara lain use case, Langkah awal perancangan pengembangan sistem informasi ini menggunakan use case diagram. Aktor yang tersedia adalah Admin dan Users. Berikut ini penggambaran use case diagram pada Gambar 3.
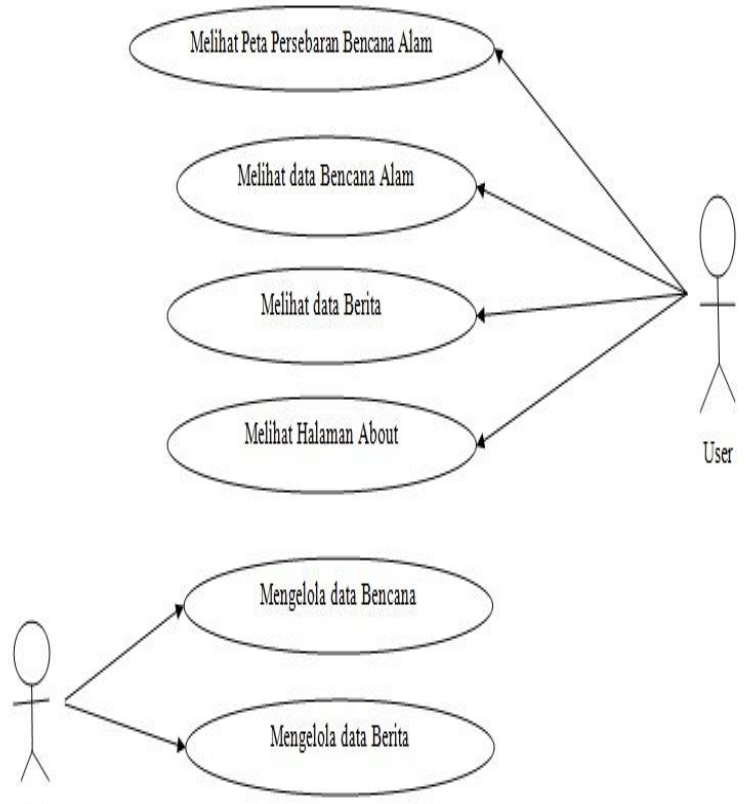

Admin
Berdasarkan Use case pada Gambar 3, Admin dan User harus terlebih dahulu membuka web sistem informasi geografi bencana alam kabupaten madiun. Perbedaan admin dan user adalah user hanya dapat mengakses peta bencana alam, sedangkan admin mempunyai hak sepenuhnya serta dapat memanipulasi data pada sistem informasi geografi bencana alam kabupaten Madiun. Admin terlebih dahulu login untuk mengelola data bencana dan data berita. Didalam mengelola data bencana dan data berita admin dapat melalukan input tambah, hapus data, serta terdapat fitur untuk mencetak data bencana.

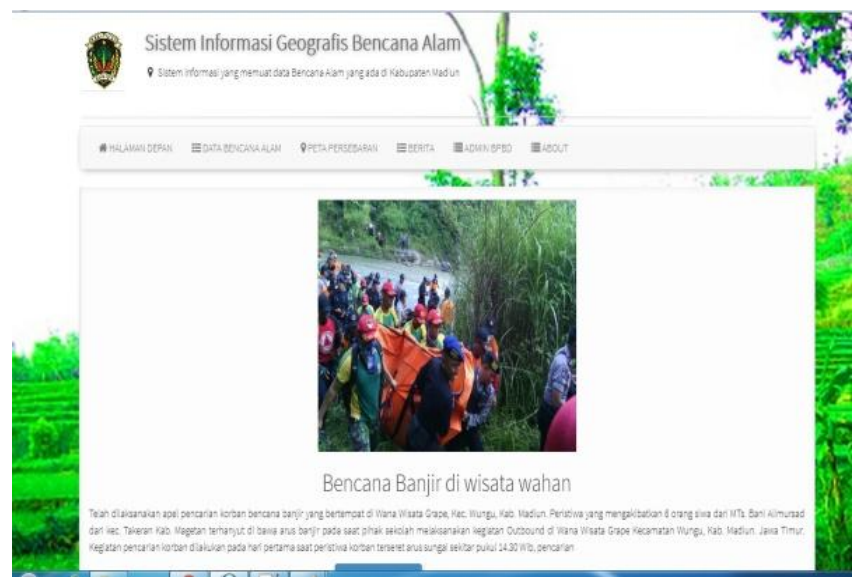

Gambar 4. Halaman Menu Utama

Halaman menu utama / home ini adalah halaman dimana pertama kali program dijalankan, halaman ini adalah tampilan untuk user, tanpa harus login.
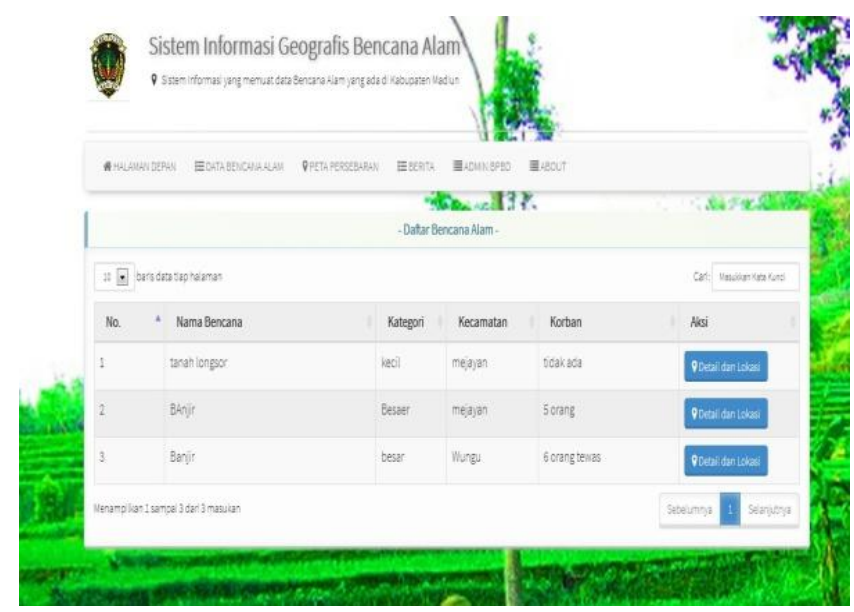

Gambar 5. Halaman data bencana

Seperti pada Gambar 5, Halaman Data Bencana ini adalah halaman pertama yang dapat dilihat oleh user. Halaman Pada menudaftar lengkap Bencana yang terjadi di kabupaten Madiun.

Gambar 3. Diagram Use Case. 


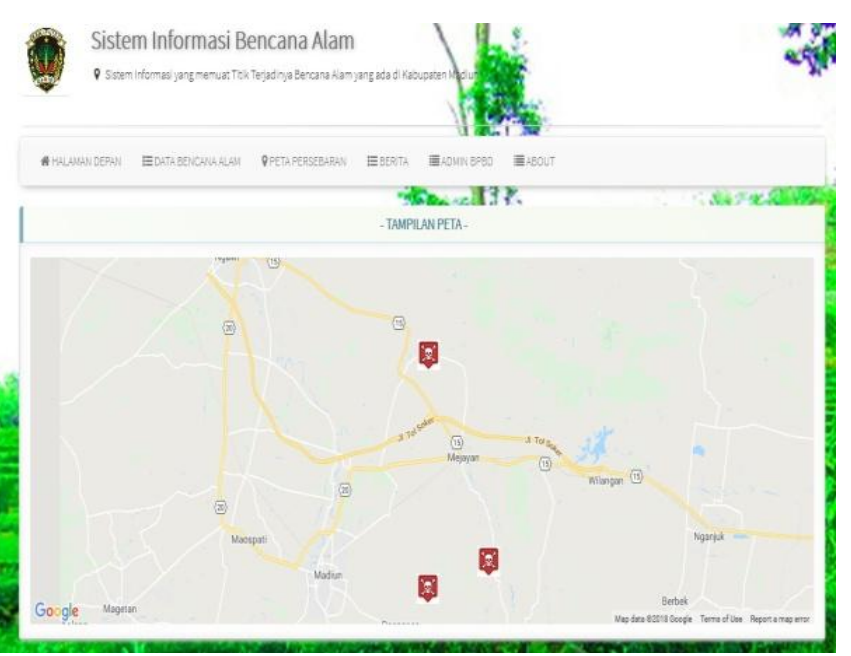

Gambar 6. Halaman Peta Bencana Kabupaten Madiun

Berdasarkan Gambar 6, Halaman Peta Bencana Kabupaten Madiun ini adalah halaman kedua yang dapat dilihat oleh user. Halaman.

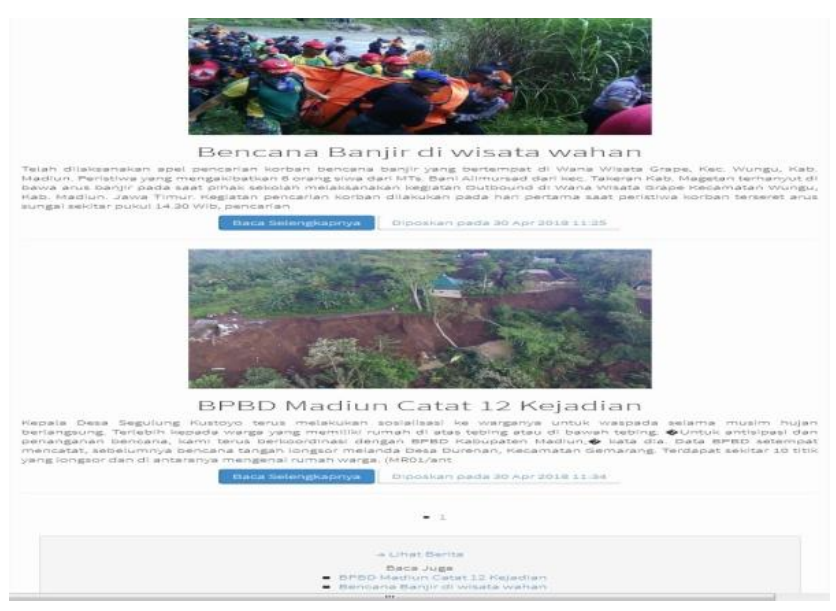

Gambar 7. Halaman Berita

Berdasarkan Gambar 7, Halaman Berita merupakan halaman dimana user dapat melihat berita seputar bencana di Kabupaten Madiun.

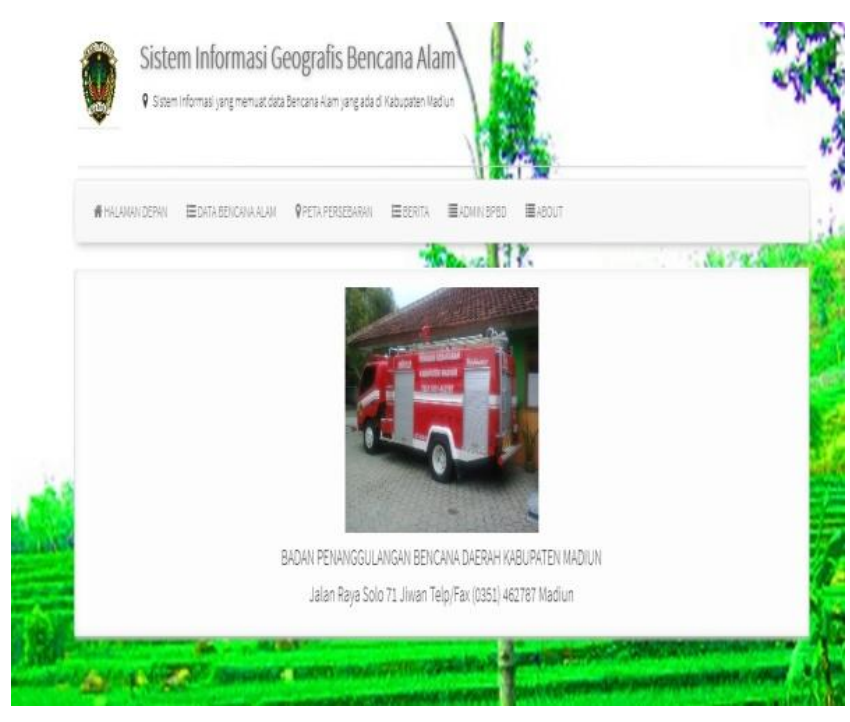

Gambar 8. Halaman About

Berdasarkan Gambar 8, Halaman About merupakan halaman dimana user dapat melihat profil singkat BPBD kabupaten Madiun.

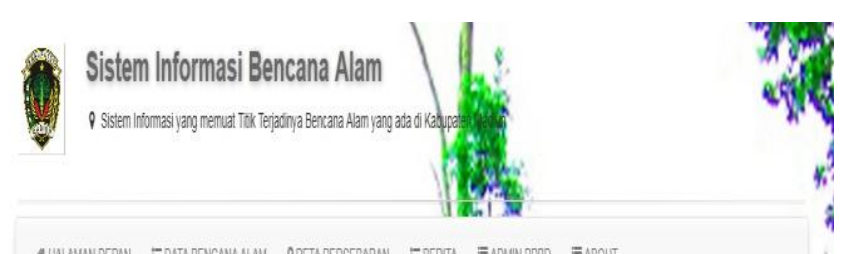

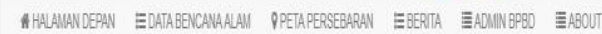

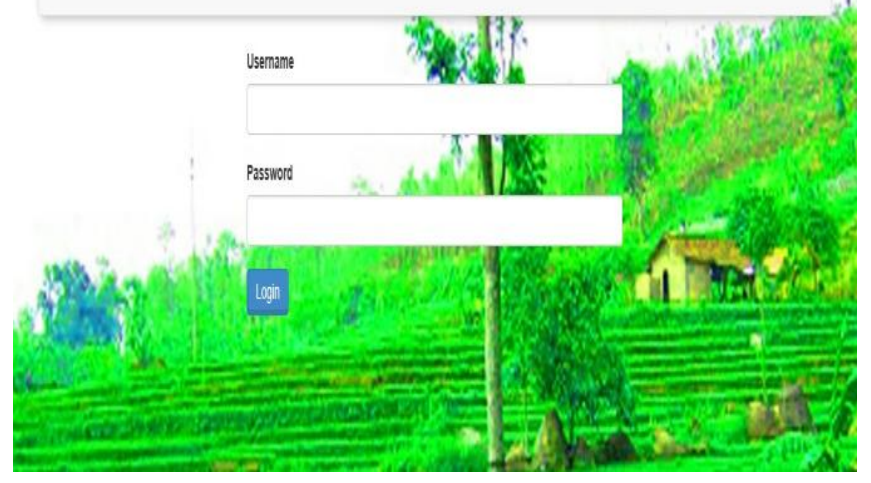

Gambar 9. Halaman Login

Berdasarkan Gambar 9, Halaman Login merupakan halaman dimana menjadi akses masuk menjadi Admin yang memiliki akses penuh terhadap website Sistem Informasi Bencana Pada Kabupaten Madiun. 


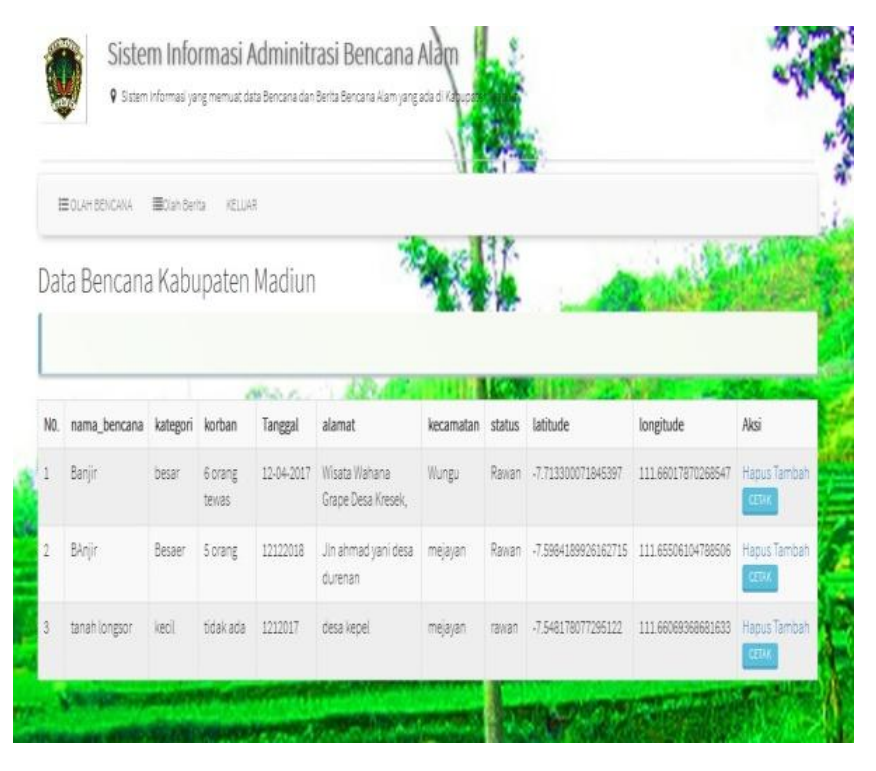

Gambar 10. Halaman Admin Mengelola Data Bencana

Berdasarkan Gambar 10, Halaman admin mengelola data bencana ini adalah menu halaman yang hanya bisa diakses oleh admin. Pada menu ini seorang admin bisa melakukan pengolahan aplikasi ini dengan melakukan penginputan, pencetakan data dan hapus data bencana.

\section{Seputar Bencana Madin B Badan Peranggianan Bencana Alamk Kabipaten Madiun}

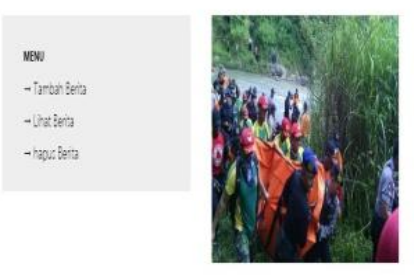

\section{Bencana Baniji di wisata wahan}

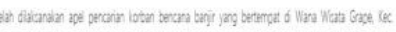

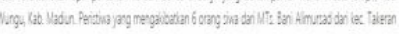

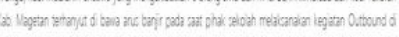

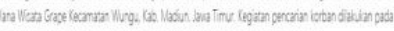

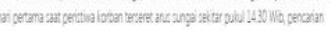

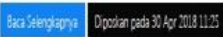

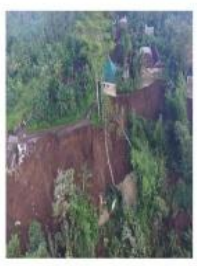

BPBD Madiun Catat 12 Kejadian

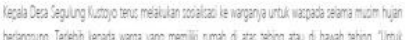

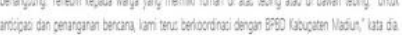

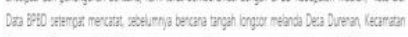

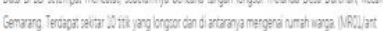

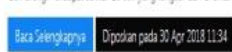

\section{Gambar 11. Halaman Admin Mengelola Data Berita}

Berdasarkan Gambar 11, Halaman admin Mengelola data berita ini adalah menu halaman yang hanya bisa diakses oleh admin Untuk bisa masuk menu ini admin atau operator harus login terlebih dahulu. Pada menu ini seorang admin bisa melakukan pengolahan data berita ini

Pengujian Sistem Informasi ini menggunakan metode black box. Identifikasi dan rencana pengujian menggunakan metode pengujian Black Box Testing yang merupakan metode perancangan data uji yang didasarkan pada spesifikasi perangkat.
Tabel 1. Pengujian Black Box User

\begin{tabular}{|c|c|c|c|c|}
\hline No. & Butir Uji & $\begin{array}{c}\text { Tingkat } \\
\text { Pengujian }\end{array}$ & $\begin{array}{c}\text { Jenis } \\
\text { Pengujian }\end{array}$ & $\begin{array}{c}\text { Hasil } \\
\text { Berhasil/Gagal }\end{array}$ \\
\hline 1. & Halaman Utama & $\begin{array}{l}\text { Pengujian } \\
\text { Unit }\end{array}$ & Black Box & Berhasil \\
\hline 2. & $\begin{array}{l}\text { Halaman Data } \\
\text { Bencana }\end{array}$ & $\begin{array}{l}\text { Pengujian } \\
\text { Unit }\end{array}$ & Black Box & Berhasil \\
\hline 3. & $\begin{array}{l}\text { Halaman Peta } \\
\text { Persebaran } \\
\text { Bencana }\end{array}$ & $\begin{array}{l}\text { Pengujian } \\
\text { Unit }\end{array}$ & Black Box & Berhasil \\
\hline 4. & Halaman Berita & $\begin{array}{l}\text { Pengujian } \\
\text { Unit }\end{array}$ & Black Box & Berhasil \\
\hline 5. & Login Admin & $\begin{array}{l}\text { Pengujian } \\
\text { Unit }\end{array}$ & Black Box & Berhasil \\
\hline 6. & Halaman About & $\begin{array}{l}\text { Pengujian } \\
\text { Unit }\end{array}$ & Black Box & Berhasil \\
\hline
\end{tabular}

Tabel 2. Pengujian Black Box Admin

\begin{tabular}{|c|c|c|c|c|}
\hline No. & Butir Uji & $\begin{array}{c}\text { Tingkat } \\
\text { Pengujian }\end{array}$ & $\begin{array}{c}\text { Jenis } \\
\text { Pengujian }\end{array}$ & $\begin{array}{c}\text { Hasil } \\
\text { Berhasil/Gagal }\end{array}$ \\
\hline 1. & Halaman Login & $\begin{array}{l}\text { Pengujian } \\
\text { Unit }\end{array}$ & Black Box & Berhasil \\
\hline 2. & $\begin{array}{l}\text { Halaman Olah } \\
\text { Data Bencana }\end{array}$ & $\begin{array}{l}\text { Pengujian } \\
\text { Unit }\end{array}$ & Black Box & Berhasil \\
\hline 3. & $\begin{array}{l}\text { Tambah Data } \\
\text { Bencana }\end{array}$ & $\begin{array}{l}\text { Pengujian } \\
\text { Unit }\end{array}$ & Black Box & Berhasil \\
\hline 4. & $\begin{array}{l}\text { Hapus } \\
\text { Bencana }\end{array}$ & $\begin{array}{l}\text { Pengujian } \\
\text { Unit }\end{array}$ & Black Box & Berhasil \\
\hline 5. & $\begin{array}{ll}\text { Cetak Data } \\
\text { Bencana }\end{array}$ & $\begin{array}{l}\text { Pengujian } \\
\text { Unit }\end{array}$ & Black Box & Berhasil \\
\hline 6. & $\begin{array}{l}\text { Halaman Olah } \\
\text { Data Berita }\end{array}$ & $\begin{array}{l}\text { Pengujian } \\
\text { Unit }\end{array}$ & Black Box & Berhasil \\
\hline 7. & Tambah Berita & $\begin{array}{l}\text { Pengujian } \\
\text { Unit }\end{array}$ & Black Box & Berhasil \\
\hline 8. & Hapus Berita & $\begin{array}{l}\text { Pengujian } \\
\text { Unit }\end{array}$ & Black Box & Berhasil \\
\hline 9. & Logout & $\begin{array}{l}\text { Pengujian } \\
\text { Unit }\end{array}$ & Black Box & Berhasil \\
\hline
\end{tabular}

Pada pengujian sistem didapatkan akurasi tingkat keberhasilan sistem sebesar 100\% dengan menggunakan 14 butir uji, baik halaman untuk user atau halaman admin.

\section{KESIMPULAN}

Pada penelitian ini, dapat diambil kesimpulan yaitu, telah dilakukan Perancangan dan pengembangan sistem informasi Geografis website ini berhasil dengan tingkat kemampuan sistem sebesar $100 \%$ pada Butir Uji. Website yang di kembangkan ini dapat digunakan untuk membantu BPBD kabupaten Madiun dalam memberikan informasi geografis terjadinya bencana yang ada di kabupaten Madiun kepada masyarakat.

\section{DAFTAR PUSTAKA}

Andre., Erdisna., Rianti. 2015, Sistem Informasi Penanggulanan Bencana Alam di kota Padang Berbasis Web Didukung Dengan Bahasa Pemograman PHP dan Database MYSQL. Jurnal KomTekInfo Fakultas Ilmu Komputer, Universitas Putra Indonesia, Padang.

Dhani, H. P. S. 2016. Comparative Study and Analysis of Software Process Models on Various Merits. International Journal of Advanced Research in Computer Science and Software Engineering. Vol.6. Issue 9. ISSN:2277 128X. 
Hamka., Qashim, Akhmad., Syarli. 2017. Sistem Informasi Geografis Kabuapaten Polewali Mandar Dengan Google Maps. Jurnal Ilmiah Ilmu Komputer. Vol. 3. No.2.

Hidayat, Cepi. Rahmat., Jamaludin, Ikbal., Mubarok, Husni. 2015. Sistem Informasi Geografi (SIG) Daerah Rawan Longsor Di Kabupaten Tasikmalaya Berbasis Web. Seminar Nasional Informatika 2015. Teknik Informatika. STMIK Tasikmalaya.

Kabupaten Madiun. 2013. Buku Kabupaten Madiun.

Pratama, O,R., Nita, Sekreningsih. 2017. RancangBangun Sistem Informasi Geografis (SIG) pada Daerah Bencana Kabupaten Madiun Berbasis Web Gis. Journal of Computer and Information Technology. Vol.1. No.1. Sekolah Tinggi Teknik Dharma Iswara Madiun.

Sagita, S.M. 2016. Sistem Informasi Geografi Bencana Banjir Pada Jakarta Selatan. Universitas Indraprasta PGRI. Jakarta Selatan.

Verma, Shikha. 2014. Analysis of Strengths and Weakness of SDLC Models. International Journal of Advance Research in Computer Science and Management Studies. Vol.2. Issue 3. ISSN: 2321-7782. 